\title{
Busulfan systemic exposure and its relationship with efficacy and safety in hematopoietic stem cell transplantation in children: a meta-analysis
}

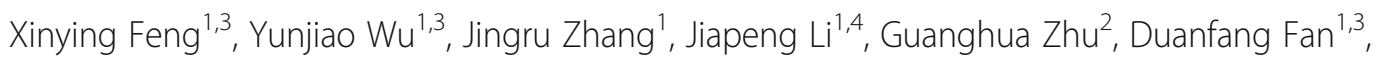
Changqing Yang ${ }^{3^{*}}$ and Libo Zhao ${ }^{1 *}$

\begin{abstract}
Background: Busulfan (Bu) is a key component of several conditioning regimens used before hematopoietic stem cell transplantation (HSCT). However, the optimum systemic exposure (expressed as the area under the concentration-time curve $[\mathrm{AUC}]$ ) of Bu for clinical outcome in children is controversial.

Methods: Research on pertinent literature was carried out at PubMed, EMBASE, Web of science, the Cochrane Library and ClinicalTrials.gov. Observational studies were included, which compared clinical outcomes above and below the area under the concentration-time curve (AUC) cut-off value, which we set as 800, 900, 1000, 1125, 1350, and $1500 \mu \mathrm{M} \times \min$. The primary efficacy outcome was notable in the rate of graft failure. In the safety outcomes, incidents of veno-occlusive disease (VOD) were recorded, as well as other adverse events.

Results: Thirteen studies involving 548 pediatric patients (aged 0.3-18 years) were included. Pooled results showed that, compared with the mean Bu AUC (i.e., the average value of AUC measured multiple times for each patient) of $>900 \mu \mathrm{M} \times$ min, the mean AUC value of $<900 \mu \mathrm{M} \times$ min significantly increased the incidence of graft failure $(\mathrm{RR}=$ $3.666,95 \% \mathrm{Cl}: 1.419,9.467)$. The incidence of VOD was significantly decreased with the mean AUC $<1350 \mu \mathrm{M} \times \mathrm{min}$ $(\mathrm{RR}=0.370,95 \% \mathrm{Cl}: 0.205-0.666)$ and $<1500 \mu \mathrm{M} \times \min (\mathrm{RR}=0.409,95 \% \mathrm{Cl}: 0182-0.920)$.

Conclusions: In children, Bu mean AUC above the cut-off value of $900 \mu \mathrm{M} \times$ min (after every 6-h dosing) was associated with decreased rates of graft failure, while the cut-off value of $1350 \mu \mathrm{M} \times$ min were associated with increased risk of VOD, particularly for the patients without VOD prophylaxis therapy. Further well-designed prospective and multi centric randomized controlled trials with larger sample size are necessary before putting our result into clinical practices.
\end{abstract}

Keywords: Busulfan, Area under the concentration-time curve, Efficacy, Veno-occlusive disease, Meta-analysis

\footnotetext{
*Correspondence: ycq0315@yahoo.com; libozhao2011@163.com

${ }^{3}$ School of Basic Medicine and Clinical Pharmacy, China Pharmaceutical University, Nanjing 211198, China

${ }^{1}$ Clinical Research Center, Beijing Children's Hospital, Capital University of Medical Sciences, Beijing 100045, China

Full list of author information is available at the end of the article
}

C C The Author(s). 2020 Open Access This article is licensed under a Creative Commons Attribution 4.0 International License, which permits use, sharing, adaptation, distribution and reproduction in any medium or format, as long as you give appropriate credit to the original author(s) and the source, provide a link to the Creative Commons licence, and indicate if changes were made. The images or other third party material in this article are included in the article's Creative Commons licence, unless indicated otherwise in a credit line to the material. If material is not included in the article's Creative Commons licence and your intended use is not permitted by statutory regulation or exceeds the permitted use, you will need to obtain permission directly from the copyright holder. To view a copy of this licence, visit http://creativecommons.org/licenses/by/4.0/. The Creative Commons Public Domain Dedication waiver (http://creativecommons.org/publicdomain/zero/1.0/) applies to the data made available in this article, unless otherwise stated in a credit line to the data. 


\section{Background}

Hematopoietic stem cell transplantation (HSCT) is widely used for the treatment of various malignancies and inherited disorders diseases. High-dose busulfan $\mathrm{Bu})$ as an alternative to total body irradiation in many pre-transplant conditioning regimens used in clinics today [1]. Although effective, $\mathrm{Bu}$ has a relatively narrow therapeutic index, low drug exposure is associated with increased risk of graft failure and disease relapse in transplant recipients [2-4], whereas high drug exposure is associated with increased frequency of hepatic complications, especially veno-occlusive disease (VOD) [5-7]. To improve treatment outcomes of $\mathrm{Bu}$, therapeutic drug monitoring (TDM) and dose adjustment, following the first dose, has highly recommended regardless of the dosing guideline was used [8]. The area under the drug plasma concentration time curve (AUC) or its counterpart, the concentration at steady state $\left(\mathrm{C}_{\mathrm{SS}}\right)$ (the AUC divided by dose frequency) best describes the relationship between the pharmacokinetic (PK) and pharmacodynamic (PD) properties of $\mathrm{Bu}$ [9].

To our knowledge, there is no conclusive evidence on the relationship between optimum exposure range of $\mathrm{Bu}$ and its effectiveness or toxicity in children. The guidelines from the European Medicines Agency (EMA) recommended a target Bu AUC in children of 900 to $1500 \mu \mathrm{M} \times \min$ [10]. The FDA labeling recommended a target intravenous (IV) $\mathrm{Bu}$ AUC 900 to $1350 \pm 5 \% \mu \mathrm{M} \times \min$ after $6 \mathrm{~h}$ dosing [8]. The European Society for Blood and Marrow Transplantation (EBMT) guidelines recommend a total AUC after 16 doses of $90 \mathrm{mg} \times \mathrm{h} / \mathrm{L}$ (an equivalent of $1370 \mu \mathrm{M} \times \mathrm{min}$ after every $6 \mathrm{~h}$ dosage) for myeloablative exposure, without strict distinction between children and adults [11]. Numerous observational studies have recommended target $\mathrm{Bu}$ exposure ranges at different cut-off values, including 900 [2, 12-17], 1000 [18], 1225 [11], 1350 [15-17], 1500 [14] and 1575 [11] $\mu \mathrm{M} \times \min$ for every 6-h dosage. On the contrary, some observational studies found no statistically significant differences in transplant-related toxicity (TRT) or graft failure rate between different Bu AUC [19-21].

Evidence for optimum $\mathrm{Bu}$ exposure range described in these studies has obvious limitations. Frist, most of the observational studies that contributed to the aforementioned guidelines had too small a sample size and had no clear inclusion/ exclusion criteria. What's more, these studies failed to identify different patient groups of adults or children. In light of these uncertainties, we conducted this systematic review and meta-analysis to evaluate the relationship between the reported $\mathrm{Bu} \mathrm{AUC}$ and clinical outcomes in children undergoing HSCT.

\section{Methods}

\section{Search strategy}

This meta-analysis is reported in accordance with the Cochrane Handbook for Systematic Reviews and the Meta-analysis of Observational Studies in Epidemiology guidelines [22]. Studies were accessed from the PubMed, EMBASE, Web of science, the Cochrane Library and ClinicalTrials.gov. Search terms included "busulfan" in combination with "area under the curve", "AUC", "pharmacokinetics" and "concentration". Reference lists of retrieved articles and related reviews were also examined, with no language or date restrictions.

\section{Study selection}

Two authors (X.Y.F and Y.J.W) independently applied the inclusion criteria to all identified and retrieved articles, if the two authors could not reach a consensus, a third reviewer (J.R.Z) was brought in to resolve the disagreement. We included studies when: (i) it was an observational study; (ii) $\mathrm{Bu}$ was administered 4 times daily for 4 days (16 doses), either orally or by an IV infusion route during the conditioning regimen before HSCT; (iii) TDM was performed; (iv) AUC were reported for included patients; (v) Rate of graft failure and Bu-related adverse events at both below and above the cut-off value of the AUC were reported for included patients, or sufficient data to estimate these was provided; and (vi) sample size was $\geq 10$ patients. The exclusion criteria were as follows: (i) the object of the study was older than 18; (ii) Data came from simulated patients or pharmacokinetic models rather than real patients and; (iii) Clinical data were not presented by Bu AUC strata.

\section{Cut-off value establishment}

According to the cut-off values of target $\mathrm{Bu}$ AUC ranges recommended by guidelines from EMA [10], EBMT [11] and the observational studies that we mentioned above [2, 14-17, 20, 23-27] The stepwise cut-off values as $800,900,1000,1225,1350$, and $1500 \mu \mathrm{M} \times$ min was established.

\section{Data extraction and quality assessment}

The primary efficacy outcomes were graft failure (defined as non-engraftment or rejection). The major safety outcomes were VOD incidence and other adverse events. High-risk ratio (RR) denoted a high rate of graft failure, VOD or other adverse events.

Data abstraction was conducted independently by the same two authors (X.Y.F and Y.J.W), and any discrepancy between the investigators was resolved by a third investigator (J.R.Z). The following data were collected and organized from chosen studies: the author's name, year of publication, study design, number of patients 
included, methods for measuring Bu concentration, type of AUC (initial, mean or final), cut-off value of Bu AUC, and pre-specified study outcomes of efficacy and safety. Where the study already included the cut-off value, we considered patient groups treated with $\mathrm{Bu}$ at an AUC below the pre-defined cut-off value as the treatment group, and those above the pre-defined cut-off value as the control. Where individual patient data were available, we extracted the number of events used all our pre-defined cut-off values to divide patients into two groups in the same way. When the AUC was measured multiple times for each patient, we extracted the first dose AUC (i.e., AUC calculated from $0 \mathrm{~h}$ to $6 \mathrm{~h}$ after $\mathrm{Bu}$ administration) and the mean AUC (i.e., the average value of AUC measured multiple times for each patient). When neither first dose nor mean was available, we used the reported AUC for that patient in the article. When necessary, we contacted the article's corresponding author by email for the required information.
The quality of the included studies was independently assessed by two reviewers (X.Y.F and Y.J.W) according to the Newcastle-Ottawa Scale with a maximum score of 9 [28]. This tool consists of three major sections concerning the methodological quality: the representative, comparability and outcome of each included study. Any disagreements that arose between the reviewers were resolved through discussion. A third reviewer (J.R.Z) was available to settle disputes.

\section{Statistical analysis}

Data analysis was performed using Open Meta-Analyst software (Tufts Medical Center, Boston, MA, USA). To assess variations between studies in addition to sampling error within these, the $I^{2}$ statistic was used to assess for heterogeneity across the included studies. An $I^{2}$ value > $50 \%$ suggests substantial heterogeneity between studies. The DerSimonian-Laird was used to calculate RR and 95\% confidence interval (CI) for each study. The 95\% CI

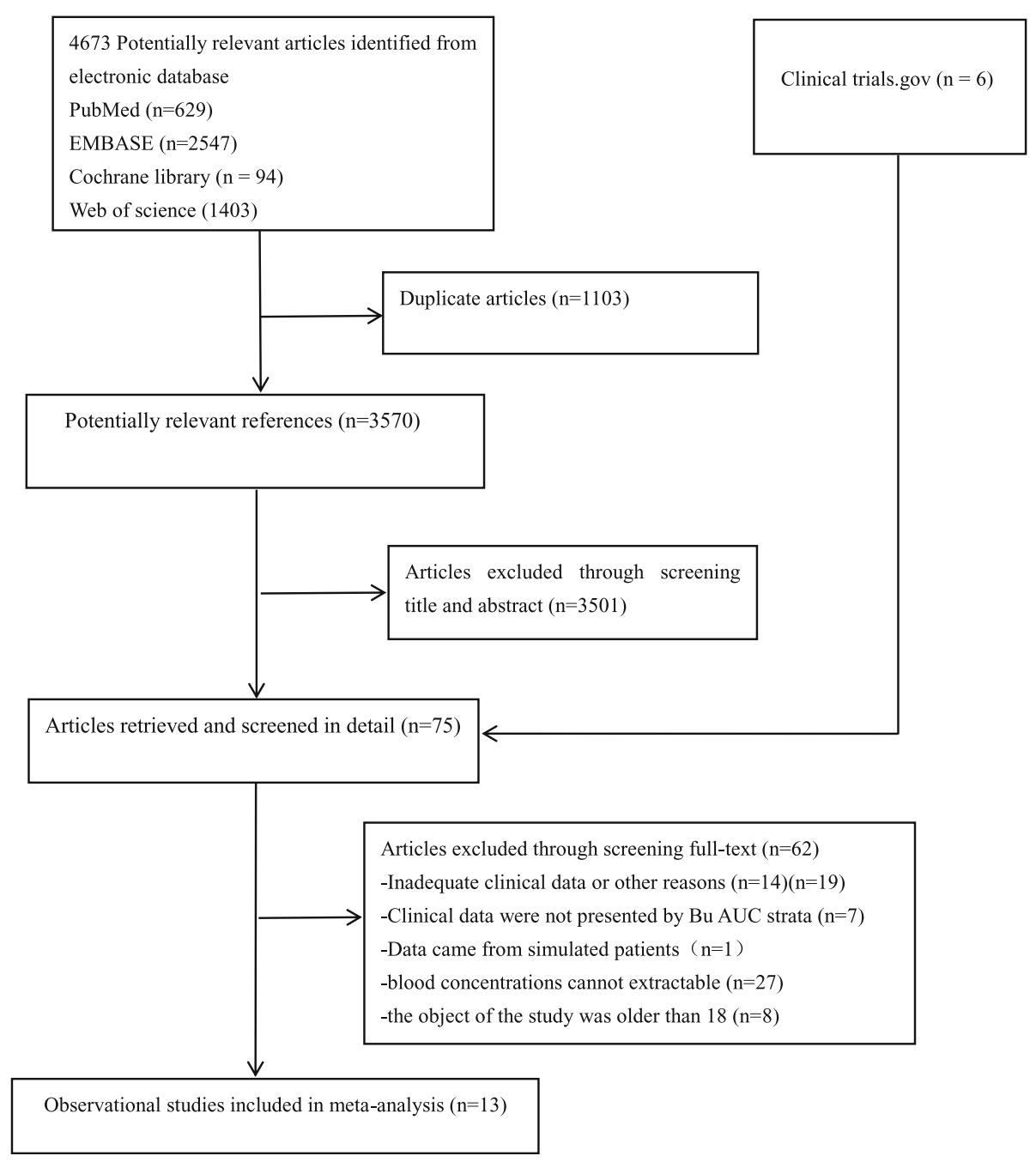

Fig. 1 Flow chart of study selection process 


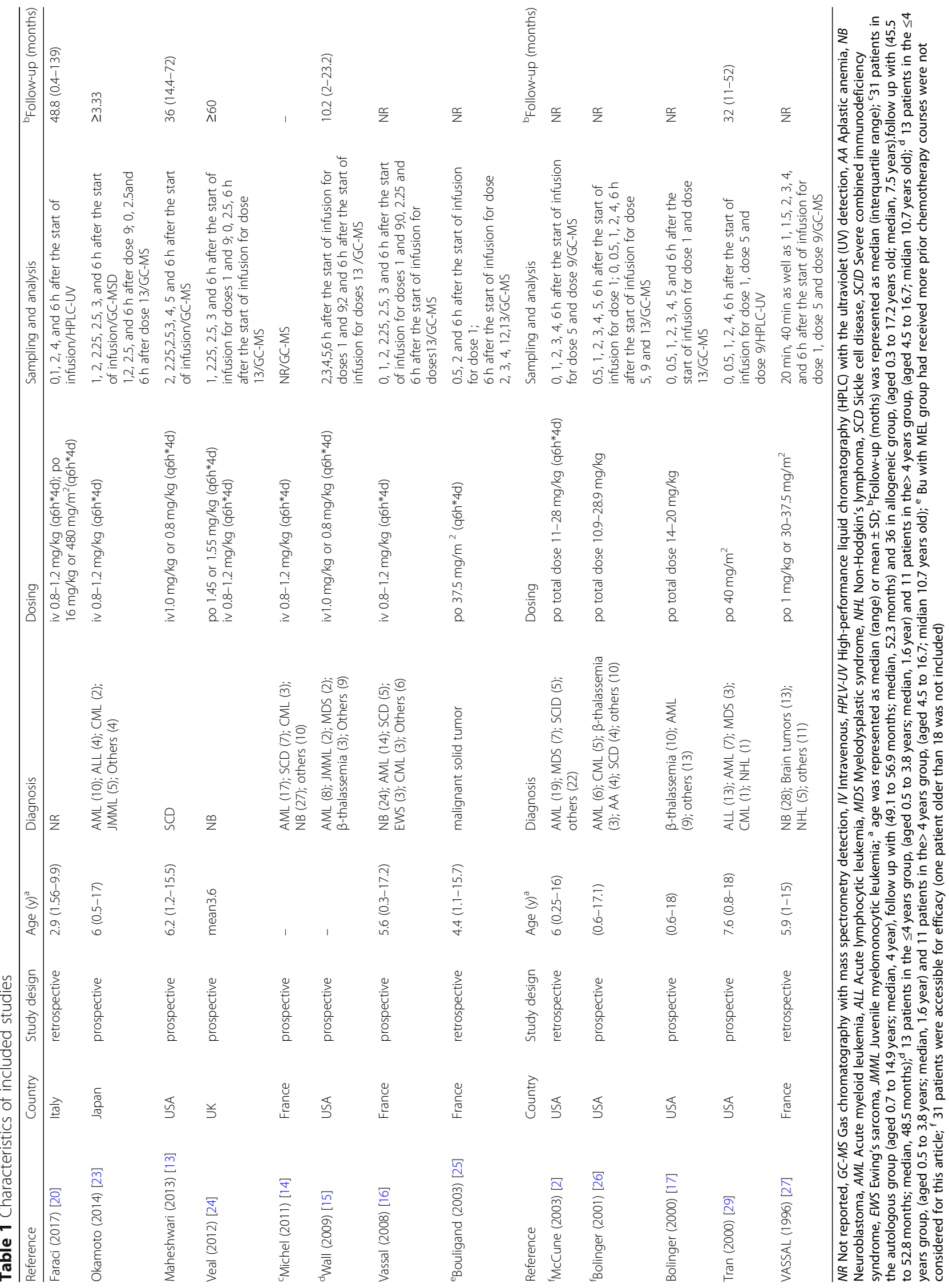


of outcome among distinct groups did not overlap, showing that outcomes were statistically significant. A $P$ value $<0.05$ was considered statistically significant.

To explore the heterogeneity among different studies, subgroup analysis was performed when more than two studies were included in the analysis of each cutoff level. For the efficacy outcome, studies were stratified by orally or an IV infusion route during the conditioning regimen before HSCT. For the safety outcome, studies were stratified by: i) studies reporting presence or absence of VOD prophylaxis therapy. ii) Orally or an IV infusion route during the conditioning regimen before HSCT. The robustness of our meta-analysis was assessed using leave-one-out approach. We isolated each study and evaluated its effect on the summary estimates and heterogeneity of the main analysis, reporting the results for sensitivity analysis when the conclusions differed.

\section{Results}

\section{Search strategy and selection criteria}

A total of 4673 articles were initially identified. Of the 3570 articles remaining after excluding duplicate publications, 3501 were excluded after screening the title and abstract because they were not relevant. An additional 62 articles were excluded during the full-text review owing to data proceeding from simulated patients, the subjects of the study being age over 18 , insufficient data on clinical outcomes, clinical data not having been presented by Bu AUC strata or Bu not having been administered 4 times daily for 4 days, among other reasons. Consequently, a total of 13 studies involving 548 patients met the inclusion criteria and, accordingly, were included for meta-analysis [2, 13-17, 20, 23-27, 29]. The literature selection process is summarized in Fig. 1.

\section{Study characteristics}

A summary of descriptions of included studies is reported in Table 1, the studies were published between 1996 and 2017. Nine [13-17, 23, 24, 26, 29] were prospective studies and four $[2,20,25,27]$ were retrospective studies. Six studies were conducted in Europe [14, 16, 20, 24, 25, 27], six studies were in United States [2, 13, 15, 17, 26, 29] and one [23] was in Japan. Bu concentrations were measured by high-performance liquid chromatography by means of ultraviolet detection [23, 29], while the remainder [2, 13$17,20,24-27]$ were measured by gas chromatography with mass spectrometry detection.

\section{Evaluation of efficacy}

Table 2 displays a summary of outcomes for each study. Table 3 display summaries of meta-analysis for efficacy,

Table 2 Outcomes and results of included studies

\begin{tabular}{|c|c|c|c|c|c|}
\hline Reference & Type of AUC & Cut-off value & Reported outcome & $\begin{array}{l}\text { Definition of graft failure } \\
\text { or rejection }\end{array}$ & Definition of VOD \\
\hline Faraci [20] & Initial & 900 & Graft failure & NR & Mcdonald criteria [30] \\
\hline Okamoto [23] & Initial & $\begin{array}{l}800 ; 900 ; 1000 ; 1225 \\
1350 ; 1500\end{array}$ & Graft failure; VOD & $\begin{array}{l}\text { Failure to reach } \mathrm{ANC}>0.5^{*} 10^{9} / \mathrm{L} \\
\text { by day } 28 \text { after transplantation }\end{array}$ & Mcdonald criteria [30] \\
\hline maheshwari [13] & Initial and mean & $1350 ; 1500$ & VOD & NR & McDonald criteria $[31]$ \\
\hline veal [24] & Mean & $1350 ; 1500$ & Hepatic toxicity or VOD & $N R$ & Bearman criteria [32] \\
\hline Michel [14] & Mean & $900 ; 1350 ; 1500$ & VOD & $N R$ & McDonald criteria [33. \\
\hline Wall [15] & Initial, mean and Final & $\begin{array}{l}800 ; 900 ; 1000 ; 1225 \\
1350 ; 1500\end{array}$ & Graft failure, VOD & $\begin{array}{l}\text { Failure to reach ANC }>0.5^{*} 10^{9} / \mathrm{L} \\
\text { at any time after transplantation }\end{array}$ & Jones criteria [34] \\
\hline vassal [16] & Mean & $900 ; 1350 ; 1500$ & Graft failure; VOD & $\begin{array}{l}\text { Failure to reach ANC }>0.5 * 10^{9} / \mathrm{L} \\
\text { for three consecutive days by } \\
\text { day } 100 \text { after transplantation }\end{array}$ & Jones criteria [34] \\
\hline Bouligand [25] & Final & $1350 ; 1500$ & VOD & NR & McDonald criteria [33. \\
\hline McCune [2] & Mean & $900 ; 1350$ & Graft failure; TRT & Failure to reach $A N C>0.5 * 10^{9} / \mathrm{L}$ & Bearman criteria [32] \\
\hline Bolinger $[26]$ & Mean & $800 ; 900 ; 1000 ; 1225$ & Graft failure & $\begin{array}{l}\text { No evidence of donor cells or } \\
\text { initial evidence of donor } \\
\text { engraftment followed by full } \\
\text { autologous recovery }\end{array}$ & Bearman criteria [32] \\
\hline Bolinger [17] & Initial and mean & $800 ; 900 ; 1000 ; 1225 ;$ & Graft failure & $\begin{array}{l}\text { No evidence of donor cells or } \\
\text { initial evidence of donor } \\
\text { engraftment followed by full } \\
\text { autologous recovery }\end{array}$ & Bearman criteria [32] \\
\hline Tran [29] & Mean & $1350 ; 1500$ & VOD & $N R$ & Bearman criteria [32] \\
\hline VASSAL [27] & Initial & $1350 ; 1500$ & VOD & NR & McDonald criteria [33] \\
\hline
\end{tabular}


Table 3 Summary of meta-analyses for the incidence of graft failure

\begin{tabular}{|c|c|c|c|c|c|c|}
\hline Type of AUC & Cut-off value $\left(\mu M^{*} \min / L\right)$ & RR $(95 \% \mathrm{Cl})$ & Number of studies & $\begin{array}{l}\text { Number of participants } \\
\text { in treatment group }\end{array}$ & $\begin{array}{l}\text { Number of participants } \\
\text { in control group }\end{array}$ & $P \%$ \\
\hline \multirow[t]{4}{*}{ AUC first dose } & $<800$ verse $\geq 800$ & $2.664(0.857,8.282)$ & 4 & 24 & 67 & 0 \\
\hline & $<900$ verse $\geq 900$ & $2.208(0.686,7.107)$ & 5 & 73 & 100 & 0 \\
\hline & $<1000$ verse $\geq 1000$ & $1.544(0.315,7.561)$ & 4 & 48 & 43 & 0 \\
\hline & $<1225$ verse $\geq 1225$ & $1.007(0.222,4.578)$ & 4 & 66 & 25 & 0 \\
\hline \multirow[t]{4}{*}{ AUC mean } & $<800$ verse $\geq 800$ & $5.296(1.389,20.191)$ & 3 & 22 & 78 & 0 \\
\hline & $<900$ verse $\geq 900$ & $3.666(1.419,9.467)$ & 7 & 59 & 216 & 0 \\
\hline & $<1000$ verse $\geq 1000$ & $1.245(0.267,5.809)$ & 4 & 62 & 38 & 0 \\
\hline & $<1225$ verse $\geq 1225$ & $0.559(0.125,2.505)$ & 4 & 78 & 22 & 0 \\
\hline
\end{tabular}

$\mathrm{Cl}$ Confidence interval

Forest plots are shown in Fig. 2. Raw data were shown in Supplementary data (Table S1 and Figures S1-S12).

Our meta-analysis demonstrated that there were no significant first dose AUC cut-off values for efficacy. We found the cut-off level (AUC mean) of $<900 \mu \mathrm{M} \times$ min to be significantly associated with higher incidence of graft failure ( $R R=3.666,95 \% \mathrm{CI}$ : 1.419, 9.467).

Subgroup analyses showed that the incidence of graft failure significantly decreased above a cut-off level with mean AUC $900 \mu \mathrm{M} \times$ min in the subgroup of administration by an IV infusion route alone $(R R=9.718 ; 95 \%$ CI: 1.499-62.989), There were no significant differences at other cut-off levels (Table 4).

Sensitivity analysis on each study's effect on the summary estimates for efficacy was shown in Supplementary data (Table S3), which illustrated that our results were not driven by any single study, as the RRs remained stable.

\section{Evaluation of safety}

A summary of primary and subgroup analysis for safety are shown in Table 5 and Table 6. Forest plots are shown in Fig. 3 and Fig. 4. Raw data were shown in Supplementary data (Table S2 and Figures S13-20).

The definitions of VOD varied across the 10 studies (Table 2), the incidence of VOD ranged from
$4.8 \%[2,13-17,20,24-27]$ to $40 \%$ [27]. On average, VOD occurred between 1 and 29 days after HSCT. Our meta-analysis demonstrated a significantly lower incidence of VOD with mean AUC below cut-off levels of $1350 \mu \mathrm{M} \times \min (\mathrm{RR}=0.370,95 \% \mathrm{CI}$ : $0.205-$ $0.666)$ and $1500 \mu \mathrm{M} \times \min \quad(R R=0.409, \quad 95 \% \quad \mathrm{CI}$ : 0182-0.920). In terms of the relationship between first dose AUC and clinical outcomes, our metaanalysis demonstrated there were no significant differences at all cut-off values for VOD.

Subgroup analyses showed that the rate of VOD significantly decreased below a cut-off level with mean AUC $1350 \mu \mathrm{M} \times$ min in the subgroup of without VOD prophylaxis therapy $(\mathrm{RR}=0.349 ; 95 \% \mathrm{CI}: 0.182-0.670)$, administration by an IV infusion route alone $(R R=0.378$; 95\% CI: $0.158-0.906)$ or not (either administration by an IV infusion route or by oral) ( $\mathrm{RR}=0.363$; 95\% CI: $0.163-$ $0.805)$. There were no significant differences at other cutoff levels.

For others toxic effects, the relationship of $\mathrm{Bu}$ AUC with graft versus-host disease (GVHD) was not found, although two studies $[35,36]$ reported a higher incidence of GVHD when Bu/cyclophosphamide was combined with melphalan. Regarding neurotoxicity, as benzodiazepine or phenytoin was routinely given for
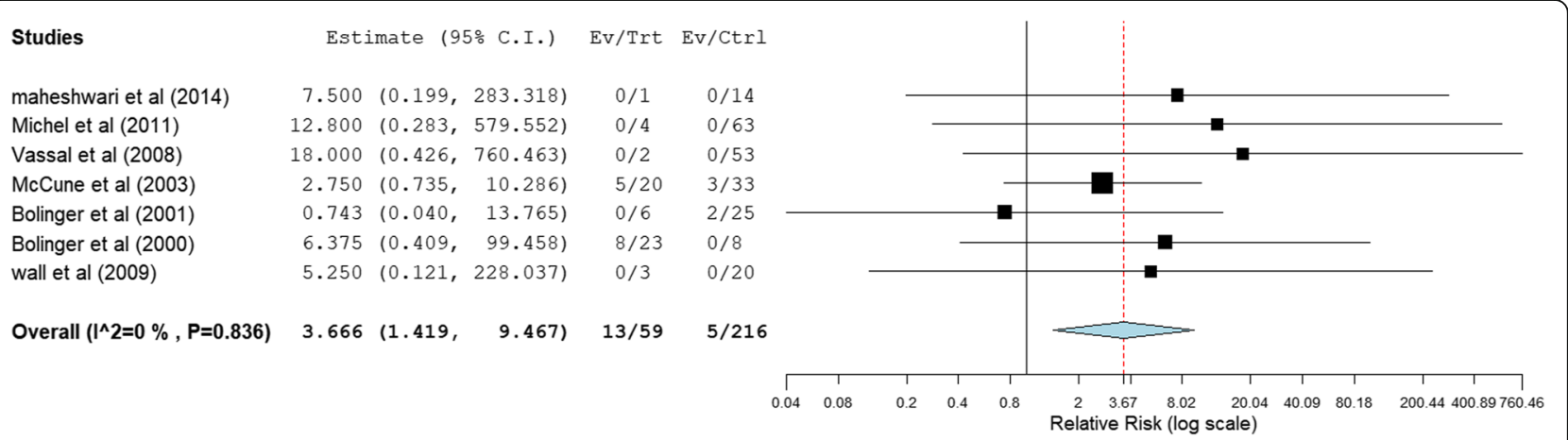

Fig. 2 Meta-analysis for rate of graft failure (mean AUC of $<900 \mu \mathrm{M} \times$ min comparison with $\geq 900 \mu \mathrm{M} \times \min$, RR $<1$ favors $\geq 900 \mu \mathrm{M} \times$ min) 
Table 4 Summary of subgroup analysis for the incidence of graft failure

\begin{tabular}{|c|c|c|c|c|c|c|c|}
\hline Subgroup & & $\begin{array}{l}\text { Cut-off value } \\
\left(\mu M^{*} \min / L\right)\end{array}$ & RR $(95 \% \mathrm{Cl})$ & $\begin{array}{l}\text { Number } \\
\text { of studies }\end{array}$ & $\begin{array}{l}\text { Number of participants } \\
\text { in treatment group }\end{array}$ & $\begin{array}{l}\text { Number of participants } \\
\text { in control group }\end{array}$ & PO \\
\hline \multirow[t]{8}{*}{ Administration route } & \multirow[t]{4}{*}{ IV Bu } & $\leq 800$ versus $>800$ & $11.282(0.930,136.897)$ & 2 & 2 & 36 & 0 \\
\hline & & $\leq 900$ versus $>900$ & $9.718(1.499,62.989)$ & 4 & 10 & 150 & 0 \\
\hline & & $\leq 1000$ versus $>1000$ & $0.418(0.030,5.850)$ & 2 & 23 & 15 & 0 \\
\hline & & $\leq 1225$ versus $>1225$ & $0.139(0.011,1.729)$ & 2 & 32 & 6 & 0 \\
\hline & \multirow[t]{4}{*}{ Oral Bu } & $\leq 800$ versus $>800$ & $3.904(0.800,19.055)$ & 2 & 20 & 42 & 0 \\
\hline & & $\leq 900$ versus $>900$ & $2.613(0.869,7.860)$ & 3 & 49 & 66 & 0 \\
\hline & & $\leq 1000$ versus $>1000$ & $2.189(0.328,14.587)$ & 2 & 39 & 23 & 0 \\
\hline & & $\leq 1225$ versus $>1225$ & $1.197(0.186,7.720)$ & 2 & 46 & 16 & 0 \\
\hline
\end{tabular}

Cl Confidence interval, NA Not applicable, IV Intravenous

seizure prophylaxis, the incidence of neurotoxicity was relatively low. We could not pool the data to perform a meta-analysis. Therefore, an association between AUC and other toxic effects could not be evaluated.

On each study's effect on the summary estimates showed that exclusion of studies by Wallet al [15], Bouligand et al. [25] and Tran et al. [29] resulted in an insignificant difference at a cut-off level of $1500 \mu \mathrm{M} \times$ min Raw data were shown in Supplementary data (Table S4).

\section{Quality assessment}

The quality assessment of the included studies is presented in Supplementary Table S5. Overall, the subjects included were representative, and ascertainment of exposure was confirmed by secure record, six studies were comparable on basis of main factors [2, 14-16, 24, 25], and seven studies were comparable on two or more factors $[13,17,20,23,26,27,29]$. Outcome assessment was based on pharmacy and medical records, the follow-up period was sufficient for outcomes to occur, and adequacy of follow-up of cohorts. According to the NOS tool, the quality assessment showed that two studies $[17,26]$ were scored 6 stars, four studies 7 stars $[20,25,27,29]$, three studies [13, 16, 23] 8 stars, and four studies [2, 14, 15, 24] 9 stars. No study was excluded after rating because the study quality was always above 5 stars.

\section{Discussion}

As a bifunctional alkylating agent, $\mathrm{Bu}$ is a key component of several conditioning regimens used before HSCT. It has been demonstrated that low plasma $\mathrm{Bu}$ exposure is associated with potentially fatal outcomes including graft failure, whereas high exposure is associated with toxicity, such as $\operatorname{VOD}[3,5,7]$. Due to the high inter- and intra-patient variability in the PK profile following oral and IV infusion [10], major guidelines support and recommend TDM for $\mathrm{Bu}$ to improve transplant outcomes [9, 26, 37], although the exact therapeutic window in children remains inconclusive.

Our meta-analysis revealed that a $\mathrm{Bu}$ mean AUC above the value $900 \mu \mathrm{M} \times$ min is associated with lower incidence of graft failure. This lower threshold of exposure is similar to the guideline recommendation [8]. We conducted a subgroup analysis by orally or by an IV infusion route during the conditioning regimen before HSCT, thereby demonstrating that the incidence of graft failure significantly decreased at a cut-off level of $>900 \mu \mathrm{M} \times$ min in subgroup of administration by an IV infusion route. As we know, oral $\mathrm{Bu}$ presents a wide inter- and intrapatient variability of plasma exposures, especially in young children, which results in poor clinical outcomes [35]. That might explain why the oral $\mathrm{Bu}$ subgroup did not show significance at the $900 \mu \mathrm{M} \times$ min cut-off level. Our sensitivity analysis further validated the cut-off value

Table 5 Summary of meta-analyses for the incidence of VOD

\begin{tabular}{lllllll}
\hline Type of AUC & $\begin{array}{l}\text { Cut-off value } \\
\left(\mu \mathrm{M}^{*} \mathrm{~min} / \mathrm{L}\right)\end{array}$ & RR $(95 \% \mathrm{Cl})$ & $\begin{array}{l}\text { Number } \\
\text { of studies }\end{array}$ & $\begin{array}{l}\text { Number of participants } \\
\text { in treatment group }\end{array}$ & $\begin{array}{l}\text { Number of participants } \\
\text { in control group }\end{array}$ \\
\hline AUC first dose & $\leq 1350$ versus $>1350$ & $0.562(0.126,2.496)$ & 3 & 51 & 23 & 44 \\
& $\leq 1500$ versus $>1500$ & $0.761(0.435,1.333)$ & 4 & 87 & 61 & 0 \\
AUC mean & $\leq 1350$ versus $>1350$ & $0.370(0.205,0.666)$ & 7 & 207 & $28.96 \%$ \\
& $\leq 1500$ versus $>1500$ & $0.409(0.182,0.920)$ & 5 & 163 & 0 \\
\hline
\end{tabular}


Table 6 Summary of subgroup analysis for incidence of VOD

\begin{tabular}{|c|c|c|c|c|c|c|c|}
\hline Sub group & & $\begin{array}{l}\text { Cut-off value } \\
\left(\mu \mathrm{M}^{*} \min / L\right)\end{array}$ & RR $(95 \% \mathrm{Cl})$ & $\begin{array}{l}\text { Number } \\
\text { of studies }\end{array}$ & $\begin{array}{l}\text { Number of participants } \\
\text { in treatment group }\end{array}$ & $\begin{array}{l}\text { Number of participants } \\
\text { in control group }\end{array}$ & $P^{2} \%$ \\
\hline \multirow{4}{*}{$\begin{array}{l}\text { Administration } \\
\text { route }\end{array}$} & \multirow[t]{2}{*}{ IV Bu alone } & $\leq 1350$ versus $>1350$ & $0.378(0.158,0.906)$ & 3 & 106 & 30 & 0 \\
\hline & & $\leq 1500$ versus $>1500$ & $0.485(0.171,1.377)$ & 3 & 129 & 17 & 0 \\
\hline & \multirow{2}{*}{$\begin{array}{l}\text { IV Bu+ oral Bu/oral } \\
\mathrm{Bu}\end{array}$} & $\leq 1350$ versus $>1350$ & $0.363(0.163,0.805)$ & 4 & 101 & 31 & 0 \\
\hline & & $\leq 1500$ versus $>1500$ & $0.316(0.087,1.145)$ & 2 & 34 & 11 & 0 \\
\hline \multirow[t]{4}{*}{ VOD prophylaxis } & \multirow[t]{2}{*}{ Yes } & $\leq 1350$ versus $>1350$ & $0.476(0.120,1.885)$ & 1 & 42 & 15 & NA \\
\hline & & $\leq 1500$ versus $>1500$ & $0.491(0.109,2.216)$ & 1 & 56 & 11 & NA \\
\hline & \multirow[t]{2}{*}{ No } & $\leq 1350$ versus $>1350$ & $0.349(0.182,0.670)$ & 6 & 165 & 46 & 0 \\
\hline & & $\leq 1500$ versus $>1500$ & $0.380(0.145,0.994)$ & 4 & 107 & 17 & 0 \\
\hline
\end{tabular}

CI Confidence interval, NA Not applicable, IV Intravenous

$900 \mu \mathrm{M} \times \min$ for efficacy. In addition, numerous studies [19, 35] have found that the first-dose $\mathrm{Bu}$ AUC was significantly lower than the subsequent daily ones and AUC remained unchanged during the following days. However, we cannot identify the relationship between AUC at the first dose and efficacy as there is insufficient data from studies to support this. Thus, the correlation remain inconclusive and further investigation is needed.

Our meta-analysis also demonstrated that a target value of $1350 \mu \mathrm{M} \times \min$ is associated with an increased risk of VOD. This conclusion differs from the $900-1500 \mu \mathrm{M} \times$ min threshold that some publications $[11,12,15]$ have suggested. This is likely due to the fact that those studies are mainly conducted on adults and their subjects of study are relatively limited. In our subgroup analyses, we stratified studies according to administration route and whether $\mathrm{Bu}$ treatment was combined with VOD prophylaxis therapy. In subgroup patients without VOD prophylaxis therapy, a significantly decreased incidence of VOD was detected when $\mathrm{Bu}$ AUC was below the cut-off value of $1350 \mu \mathrm{M} \times$ min, which could not be seen in those patients with VOD prophylaxis therapy. Plausible explanations are as follows. First, only high-risk patients (pre-existing liver damage, history of pancreatitis, genetic polymorphisms and mutations) were considered eligible for VOD prophylaxis therapy [38], which may have physiological effects on identifying the relationship between drug exposure and VOD. Secondly, as there are only two studies that include patients with VOD prophylaxis therapy, we regard these subgroup analysis results as likely to be unreliable.

The optimum $\mathrm{Bu}$ AUC of $900-1350 \mu \mathrm{M} \times \min$ is consistent with some previous research recommendations [15, 39], but differs from a recently multicenter, retrospective cohort analysis reported by Bartelink et al. [11] which showed that, in children and young adults, the optimum $\mathrm{Bu}$ AUC is at a cumulative AUC of $78-101 \mathrm{mg} \times \mathrm{h} / \mathrm{L}$ (equivalent to $1225-1575 \mu \mathrm{M} \times$ min after every $6 \mathrm{~h}$ dosing). However, there were some discrepancies that should be noted. We enforced a restriction on enrolled patients being less than 18 years of age and to be administered with $\mathrm{Bu}$ 4 times a day for 4 days, while in the study by Bartelink et al. [11], patients older than 18 were included and $\mathrm{Bu}$ was given once or four times a day. These differences in age and frequency of administration might lead to a different optimum AUC.

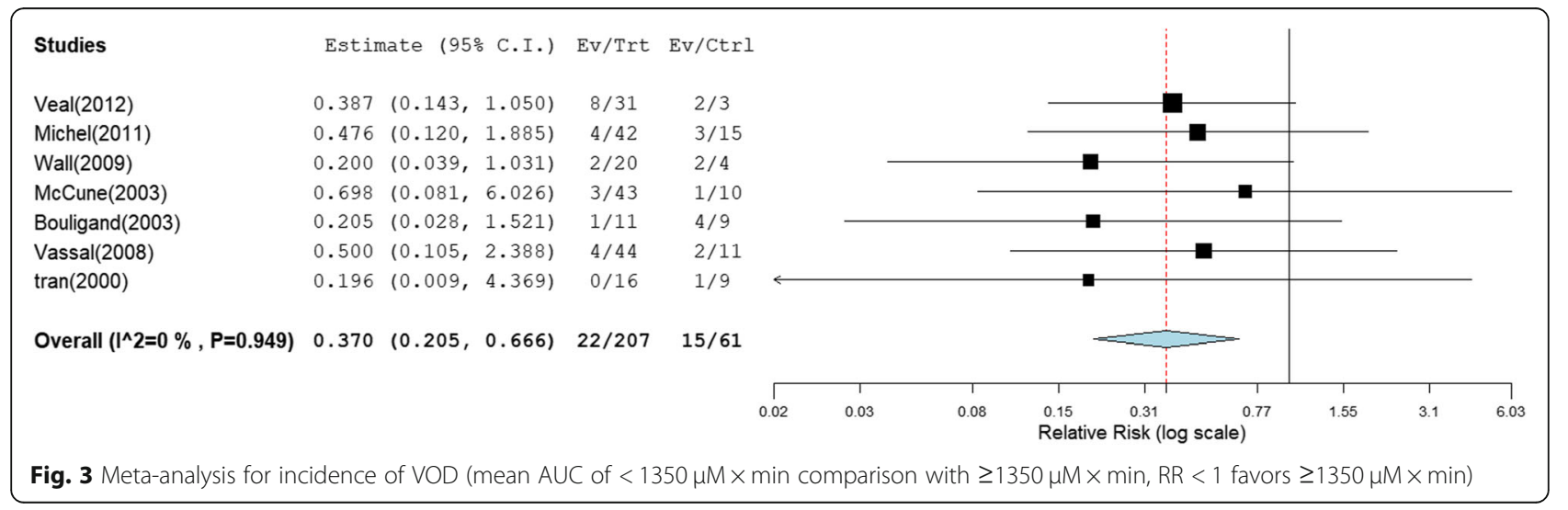




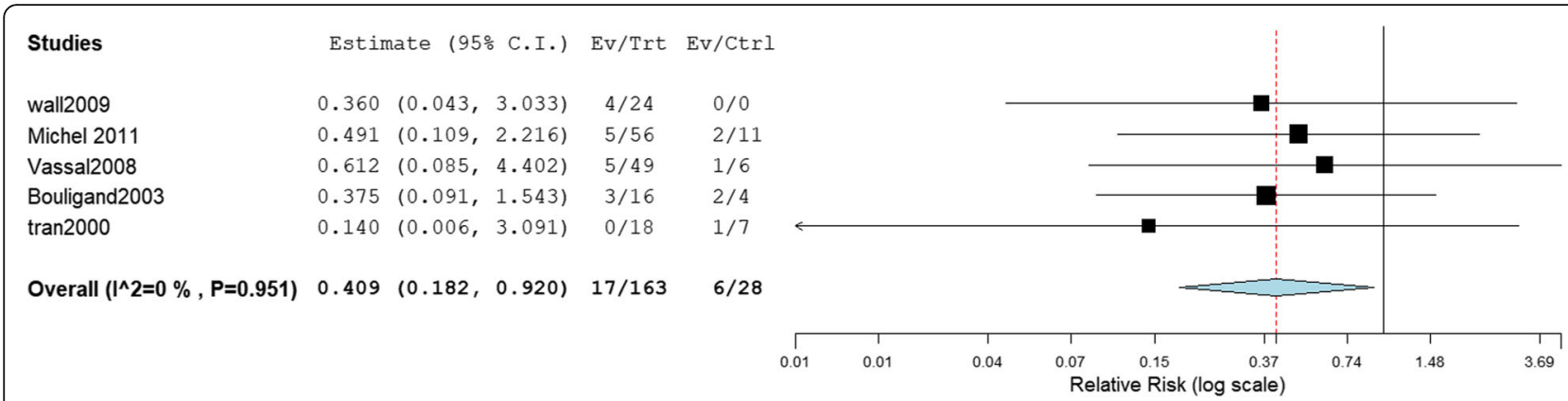

Fig. 4 Meta-analysis for incidence of VOD (mean AUC of $<1500 \mu \mathrm{M} \times$ min comparison with $\geq 1500 \mu \mathrm{M} \times$ min, RR $<1$ favors $\geq 1500 \mu \mathrm{M} \times$ min)

Our study has several strengths. First and foremost, it is the first meta-analysis focusing on the relationship of $\mathrm{Bu}$ AUC with efficacy and safety in children, providing certain reference to individualized therapy. Secondly, our meta-analysis allowed for comparison of commonly used cut-off levels for efficacy and safety in a single analysis for individual cut-off levels. Finally, our study takes the approaches of AUC estimation (AUC for the first dose or the mean value) among transplant centers into consideration, which allowed us carry out more comprehensive comparisons of $\mathrm{Bu} \mathrm{AUC}$, despite the fact that the patients came from different institutions.

We acknowledge the following limitations to our work. First, due to the shortage of available data, a detailed analysis according to different conditioning regimens and underlying disease (malignant or nonmalignant disease) was not performed, which may have drug-drug interaction, and physiological effects on identifying the cut-off value of drug exposure (patients with a different disease should be treated as separate populations as they may respond to treatment differently). Moreover, we were unable to include enough data from Asian location, because we only identified one study conducted in Japan [23]. This is a timely reminder that the optimized AUC should be considered with caution when applying the results in Asian location. Finally, the use of observational studies in the meta-analysis implies biases and confounding factors, given that these are inherent in the original studies. As such, there is a clear requirement for further research.

\section{Conclusion}

This meta-analysis demonstrated that $\mathrm{Bu}$ mean AUC above the cut-off value of $900 \mu \mathrm{M} \times$ min (after every 6-h dosing), was associated with decreased rates of graft failure, while the cut-off value of $1350 \mu \mathrm{M} \times \min$ were associated with increased risk of VOD in children, particularly for the patients without VOD prophylaxis therapy. However, our result is a synthesis of observational studies, which are the relatively low-level evidence, and should be treated carefully. Further well-designed prospective and multi centric randomized controlled trials with larger sample size are necessary before putting our result into clinical practices.

\section{Supplementary information}

Supplementary information accompanies this paper at https://doi.org/10. 1186/s12887-020-02028-6.

Additional file 1. Supplementary data.

\section{Abbreviations}

AUC: Area under the drug plasma concentration time curve; RR: Relative risk: HSCT: Hematopoietic stem cell transplantation; TDM: Therapeutic drug monitoring; VOD: Veno-occlusive disease; NOS: Newcastle-Ottawa Scale

\section{Acknowledgements}

The authors gratefully acknowledge the support by the Basic Clinical Research Cooperation Project of Capital University of Medical Sciences and the National Science and Technology Major Project of the Ministry of Science and Technology of China.

\section{Authors' contributions}

LBZ conceived and designed the study. XYF, YJW, JRZ and DFF conducted the literature search, quality assessment, data extraction and synthesis. XYF, YJW, CQY and JRZ interpreted the statistical analysis and drafted the manuscript. LBZ, CQY, JPL and GHZ provided critical revision on subsequent drafts and approved of the manuscript in its final form. All of the authors read and approved the final manuscript.

\section{Funding}

This research was financially supported by the Basic Clinical Research Cooperation Project of Capital University of Medical Sciences (grant number 17JL08), and the National Science and Technology Major Project of the Ministry of Science and Technology of China (grant number 2017ZX09304029). The funders had no role in study design, data collection and analysis, decision to publish, or preparation of manuscript.

Availability of data and materials

Raw data from this review is available in Supplementary data.

Ethics approval and consent to participate

Not applicable.

Consent for publication

Not applicable. 


\section{Competing interests}

The authors declare that they have no competing interests.

\section{Author details}

${ }^{1}$ Clinical Research Center, Beijing Children's Hospital, Capital University of Medical Sciences, Beijing 100045, China. ${ }^{2}$ Department of Hematology and Oncology, Beijing Children's Hospital, Capital University of Medical Sciences, Beijing 100045, China. ${ }^{3}$ School of Basic Medicine and Clinical Pharmacy, China Pharmaceutical University, Nanjing 211198, China. ${ }^{4}$ Department of Clinical Pharmacy, University of Michigan, Ann Arbor, MI 48109, USA.

\section{Received: 19 June 2019 Accepted: 12 March 2020} Published online: 20 April 2020

\section{References}

1. Sisler IY, Koehler E, Koyama T, Domm JA, Ryan R, Levine JE, Pulsipher MA, Haut PR, Schultz KR, Taylor DS. Impact of conditioning regimen in allogeneic Hematopoetic stem cell transplantation for children with acute Myelogenous leukemia beyond first complete remission: a pediatric Blood and marrow transplant consortium (PBMTC) study. Biol Blood Marrow Transplant. 2009;15(12):1620-7.

2. McCune JS, Gooley T, Gibbs JP, Sanders JE, Petersdorf EW, Appelbaum FR, Anasetti C, Risler L, Sultan D, Slattery JT. Busulfan concentration and graft rejection in pediatric patients undergoing hematopoietic stem cell transplantation. Bone Marrow Transplant. 2002;30(3):167-73.

3. Slattery JT, Sanders JE, Buckner CD, Schaffer RL, Lambert KW, Langer FP, Anasetti C, Bensinger WI, Fisher LD, Appelbaum FR, et al. Graft-rejection and toxicity following bone marrow transplantation in relation to busulfan pharmacokinetics. Bone Marrow Transplant. 1995;16(1):31-42.

4. Grochow LB. Busulfan disposition: the role of therapeutic monitoring in bone marrow transplantation induction regimens. Semin Oncol. 1993;20(4): $18-25$.

5. Geddes M, Kangarloo SB, Naveed F, Quinlan D, Chaudhry MA, Stewart D, Savoie ML, Bahlis NJ, Brown C, Storek J. High busulfan exposure is associated with worse outcomes in a daily i.v. busulfan and fludarabine allogeneic transplant regimen. Biol Blood Marrow Transpl J Am Soc Blood Marrow Transpl. 2008;14(2):220-8.

6. Copelan EA, Bechtel TP, Avalos BR, Elder PJ, Ezzone SA, Scholl MD, Penza SL. Busulfan levels are influenced by prior treatment and are associated with hepatic veno-occlusive disease and early mortality but not with delayed complications following marrow transplantation. Bone Marrow Transplant. 2001;27(11):1121.

7. Dix SP, Wingard JR, Mullins RE, Jerkunica I, Davidson TG, Gilmore CE, York RC, Lin LS, Devine SM, Geller RB. Association of busulfan area under the curve with veno-occlusive disease following BMT. Bone Marrow Transplant. 1996;17(2):225-30.

8. IV Busulfex Product Information. 2015. 10.Available at: http://otsukaus.com/ media/static/IVBus-ulfex. Pl.pdf. Accessed February 10, 2016.

9. Palmer J, McCune JS, Perales MA, Marks D, Bubalo J, Mohty M, Wingard JR, Paci A, Hassan M, Bredeson C, et al. Personalizing Busulfan-based conditioning: considerations from the American Society for Blood and Marrow Transplantation Practice Guidelines Committee. Biol Blood Marrow Transplant. 2016;22(11):1915-25.

10. Nguyen L, Fuller D, Lennon S, Leger F, Puozzo C. I.V. busulfan in pediatrics: a novel dosing to improve safety/efficacy for hematopoietic progenitor cell transplantation recipients. Bone Marrow Transplant. 2004;33(10):979.

11. Bartelink IH, Lalmohamed A, van Reij EM, Dvorak CC, Savic RM, Zwaveling J, Bredius RG, Egberts AC, Bierings M, Kletzel M, et al. Association of busulfan exposure with survival and toxicity after haemopoietic cell transplantation in children and young adults: a multicentre, retrospective cohort analysis. Lancet Haematol. 2016;3(11):e526-36.

12. Philippe M, Goutelle S, Guitton J, Fonrose X, Bergeron C, Girard P, Bertrand $Y$, Bleyzac N. Should busulfan therapeutic range be narrowed in pediatrics? Experience from a large cohort of hematopoietic stem cell transplant children. Bone Marrow Transplant. 2016;13(4):72-8.

13. Maheshwari S, Kassim A, Yeh RF, Domm J, Calder C, Evans M, Manes B, Bruce K, Brown V, Ho R. Targeted Busulfan therapy with a steady-state concentration of $600-700 ? \mathrm{Ng} / \mathrm{mL}$ in patients with sickle cell disease receiving HLA-identical sibling bone marrow transplant. Bone Marrow Transplant. 2013;49(3):366-9.
14. Michel G, Valteaucouanet D, Gentet JC, Esperou H, Socié G, Méchinaud F, Doz F, Neven B, Bertrand Y, Galambrun C. Weight-based strategy of dose administration in children using intravenous busulfan: clinical and pharmacokinetic results. Pediatr Blood Cancer. 2011;58(1):90-7.

15. Wall DA, Chan KW, Nieder ML, Hayashi RJ, Yeager AM, Kadota R, Przepiorka D, Mezzi K, Kletzel M, Blood P. Safety, efficacy, and pharmacokinetics of intravenous busulfan in children undergoing allogeneic hematopoietic stem cell transplantation. Pediatr Blood Cancer. 2010;54(2):291-8.

16. Vassal G, Michel G, Espérou H, Gentet JC, Valteau-Couanet D, Doz F, Mechinaud F, Galambrun C, Neven B, Zouabi H. Prospective validation of a novel IV busulfan fixed dosing for paediatric patients to improve therapeutic AUC targeting without drug monitoring. Cancer Chemother Pharmacol. 2008;61(1):113-23.

17. Bolinger AM, Zangwill AB, Slattery JT, Glidden D, Desantes K, Heyn L, Risler LJ, Bostrom B, Cowan MJ. An evaluation of engraftment, toxicity and busulfan concentration in children receiving bone marrow transplantation for leukemia or genetic disease. Bone Marrow Transplant. 2000;25(9):925-30.

18. Zwaveling J, Bredius RG, Cremers SC, Ball LM, Lankester AC, Teepe-Twiss IM, Egeler RM, Den HJ, Vossen JM. Intravenous busulfan in children prior to stem cell transplantation: study of pharmacokinetics in association with early clinical outcome and toxicity. Bone Marrow Transplant. 2005;35(1):17-23.

19. Jacobson P, Park JJ, Defor TE, Thrall M, Abel S, Krivit W, Peters C. Oral busulfan pharmacokinetics and engraftment in children with hurler syndrome and other inherited metabolic storage diseases undergoing hematopoietic cell transplantation. Bone Marrow Transplant. 2001;27(8):855.

20. Faraci M, Tinelli C, Lanino E, Giardino S, Leoni M, Ferretti M, Castagnola E, Broglia M, Silvestri AD, Martino DD. Monitoring of Busulphan concentrations in children undergone hematopoietic stem cell transplantation: Unicentric experience over 10 years. Eur J Drug Metab Pharmacokinet. 2017;43(Suppl 2):1-9.

21. Blazar BR. Relationship of plasma pharmacokinetics of high-dose oral busulfan to the outcome of allogeneic bone marrow transplantation in children with thalassemia. Bone Marrow Transplant. 1997;20(11):915-20.

22. Stroup DF, Berlin JA, Morton SC, Olkin I, Williamson GD, Rennie D, Moher D, Becker BJ, Sipe TA, Thacker SB. Meta-analysis of observational studies in epidemiology: a proposal for reporting. Meta-anal Observational Stud Epidemiol (MOOSE) Group. 2008;283(15):2008.

23. Yasuhiro O, Yoshihisa N, Yoshiyuki K, Akira K, Shunichi K, Hisato K, Yasuo H, Megumi O, Makoto K, Tetsuya M. Prospective pharmacokinetic study of intravenous busulfan in hematopoietic stem cell transplantation in 25 children. Pediatr Transplant. 2014;18(3):294-301.

24. Veal GJ, Nguyen L, Paci A, Riggi M, Amiel M, Valteau-Couanet D, Brock P, Ladenstein R, Vassal G. Busulfan pharmacokinetics following intravenous and oral dosing regimens in children receiving high-dose myeloablative chemotherapy for high-risk neuroblastoma as part of the HR-NBL-1/SIOPEN trial. Eur J Cancer. 2012;48(16):3063-72.

25. Bouligand J, Boland I, Valteau-Couanet D, Deroussent A, Kalifa C, Hartmann $\mathrm{O}$, Vassal G. In children and adolescents, the pharmacodynamics of highdose busulfan is dependent on the second alkylating agent used in the combined regimen (melphalan or thiotepa). Bone Marrow Transplant. 2003; 32(10):979-86.

26. Bolinger AM, Zangwill AB, Slattery JT, Risler $\amalg$, Sultan DH, Glidden DV, Norstad D, Cowan MJ. Target dose adjustment of busulfan in pediatric patients undergoing bone marrow transplantation. Bone Marrow Transplant. 2001;28(11):1013-8.

27. Vassal G, Koscielny S, Challine D, Valteau-Couanet D, Boland I, Deroussent A Lemerle J, Gouyette A, Hartmann O. Busulfan disposition and hepatic venoocclusive disease in children undergoing bone marrow transplantation. Cancer Chemother Pharmacol. 1995;37(3):247-53.

28. Wells G, Shea B, O'Connell J. The Newcastle-Ottawa Scale (NOS) for Assessing The Quality of Nonrandomised Studies in Meta-analyses, vol. 7; 2014.

29. Tran HT, Madden T, Petropoulos D, Worth LL, Felix EA, Sprigg-Saenz HA, Choroszy M, Danielson M, Przepiorka D, Chan KW. Individualizing high-dose oral busulfan: prospective dose adjustment in a pediatric population undergoing allogeneic stem cell transplantation for advanced hematologic malignancies. Bone Marrow Transplant. 2000;26(5):463.

30. Mcdonald GB, Sharma P, Matthews DE, Shulman HM, Thomas ED. Venocclusive disease of the liver after bone marrow transplantation: diagnosis, incidence, and predisposing factors. Hepatology. 1984;4(1): $116-22$. 
31. Deleve LD, Shulman HM, Mcdonald GB. Toxic injury to hepatic sinusoids: sinusoidal obstruction syndrome (veno-occlusive disease). Semin Liver Dis. 2002;22(01):27-42.

32. Bearman Sl, Appelbaum FR, Buckner CD, Petersen FB, Fisher LD, Clift RA, Thomas ED. Regimen-related toxicity in patients undergoing bone marrow transplantation. J Clin Oncol Off J Am Soc Clin Oncol. 1988;6(10):1562-8

33. Mcdonald GB, Hinds MS, Fisher LD, Schoch HG, Wolford IL, Banaji M, Hardin BJ, Shulman HM, Clift RA. Veno-occlusive disease of the liver and multiorgan failure after bone marrow transplantation: a cohort study of 355 patients. Ann Intern Med. 1993;118(4):255.

34. Jones RJ, Lee KS, Beschorner WE, Vogel VG, Grochow LB, Braine HG, Vogelsang GB, Sensenbrenner LL, Santos GW, Saral R. Venoocclusive disease of the liver following bone marrow transplantation. Transplantation. 1987; 44(6):778-83.

35. Mårtensson T, Priftakis P, Casswall T, Ringdén O, Mattsson J, Remberger M, Hassan M, Gustafsson B. Increased risk of gastrointestinal acute GVHD following the addition of melphalan to busulfan/cyclophosphamide conditioning. Pediatr Transplant. 2013;17(3):285-93.

36. Malär R, Sjöö F, Rentsch K, Hassan M, Güngör T. Therapeutic drug monitoring is essential for intravenous busulfan therapy in pediatric hematopoietic stem cell recipients. Pediatr Transplant. 2011;15(6):580-8.

37. Zao JH, Schechter T, Liu WJ, Gerges S, Gassas A, Egeler RM, Grunebaum E, Dupuis LL. Performance of Busulfan dosing guidelines for pediatric hematopoietic stem cell transplant conditioning. Biol Blood Marrow Transplant. 2015;21(8):1471-8.

38. Corbacioglu S, Cesaro S, Faraci M, Valteaucouanet D, Gruhn B, Rovelli A, Boelens JJ, Hewitt A, Schrum J, Schulz AS. Defibrotide for prophylaxis of hepatic veno-occlusive disease in paediatric haemopoietic stem-cell transplantation: an open-label, phase 3, randomised controlled trial. Lancet. 2012;379(9823):1301-9.

39. Javid G, Antonella I, Alessia Francesca M, Aurèlie P, Laurent N, Cristiano I, Vincenzo D, Pietro S, Marco M, Marco A. New insights into the pharmacokinetics of intravenous busulfan in children with sickle cell anemia undergoing bone marrow transplantation. Pediatr Blood Cancer. 2015;62(4): 680-6.

\section{Publisher's Note}

Springer Nature remains neutral with regard to jurisdictional claims in published maps and institutional affiliations.

Ready to submit your research? Choose BMC and benefit from:

- fast, convenient online submission

- thorough peer review by experienced researchers in your field

- rapid publication on acceptance

- support for research data, including large and complex data types

- gold Open Access which fosters wider collaboration and increased citations

- maximum visibility for your research: over $100 \mathrm{M}$ website views per year

At BMC, research is always in progress.

Learn more biomedcentral.com/submissions 